\title{
イオン液体を用いた繊維強化熱可塑性樹脂プリプレグの 作製と機械的特性の評価
}

\author{
中村 幸一*1, 平山 紀夫*2
}

(2019 年 1 月 27 日受付)

\author{
Fiber-Reinforced Thermoplastic Prepregs Using Ionic Liquids: \\ Fabrication and Evaluation of Mechanical Properties
}

\author{
Koichi NAKAmURA*1 and Norio Hirayama*2
}

(Received January 27, 2019)

\begin{abstract}
Generally, the viscosity of thermoplastic resin is considerably higher than that of thermosetting resin, even if it melts at a high temperature. Furthermore, because the thermoplastic resin is difficult to dissolve in a solvent, it is difficult to prepare a prepreg by the solvent methods used for preparing a thermosetting resin. Therefore, when molding fiber-reinforced thermoplastic (FRTP), impregnation of the thermoplastic resin into the reinforcing fibers has become a serious problem. In this study, we propose a novel method for manufacturing the FRTP prepreg, in that the thermoplastic resin is dissolved with an ionic liquid and impregnated with a reinforcing fiber. Unlike organic solvents, ionic liquids have a low environmental burden and can sufficiently dissolve thermoplastic resins; thus, ionic liquids are suitable for manufacturing FRTP prepregs. In this study, a prepreg was prepared by dissolving polyamide and polyethersulfone resins in an ionic liquid and impregnating it with a glass fiber, and the FRTP was molded using this prepreg. The optimum conditions for polymer dissolution in ionic liquids were found by prototyping and evaluating the prepreg under various polymer-dissolution conditions. It was confirmed that the FRTP using the prepreg showed a good resin impregnation state and mechanical properties superior to those of FRTP produced by the conventional film-stacking method.
\end{abstract}

Key words: FRTP, Ionic liquid, Prepreg, Thermoplastic resin

\section{1. 緒言}

繊維強化プラスチックは，熱硬化性樹脂をマトリック スとする䋊維強化プラスチック（fiber reinforced thermosetting plastic; FRP) と熱可塑性樹脂をマトリックス とする纎維強化熱可塑性プラスチック (fiber reinforced thermoplastic; FRTP) に大別される。従来から FRPを 成形する時には，プリプレグ1) (pre-impregnated mate-

*1 日東紡績株式会社ファイバー研究開発センター 課長 Manager, Fiber R\&D Center, Nitto Boseki Co., LTD,

*2 日本大学生産工学部機械工学科 教授（275-8575 千 葉県習志野市泉町 1-2-1)

Professor, Department of Mechanical Engineering, College of Industrial Technology, Nihon University rial; Prepreg）と呼ばれる中間成形材料が広く使用され ている2).このプリプレグは, 強化繊維束に未硬化の熱硬 化性樹脂を成形工程とは別の工程で予め含浸させ, 効率 よく高品質な FRP 成形品を得るための中間材料であ る.プリプレグを利用した FRP の成形では, 賦型の前 に樹脂の含浸工程を先行させることで, 高い繊維含有 率, 含浸性 (低ボイド), 繊維配向角の精密な制御, 成形 工程の自動化・省力化等, 多くの利点がある.この FRP のプリプレグの製法は, 溶媒法とホットメルト法（無溶 媒法)の 2 つに大きく分類される. 溶媒法は溶液法, ウ工 ット法とも呼ばれ, 樹脂を溶媒 (溶剤) に溶解し, 強化 繊維束を溶液に浸漬・含浸させたのち, 溶媒を加熱によ り取り除いてプリプレグを連続的に作製する方法1 る.ホットメルト法は, 予め用意された離型シートにコ ーティングした樹脂やシート状の樹脂を引き揃えた強化 
Table 1 Thermoplastic resins soluble in ionic liquid.

\begin{tabular}{lccccccc}
\hline \hline \multirow{2}{*}{ Ionic liquids } & \multicolumn{7}{c}{ Thermoplastics } \\
\cline { 2 - 7 } & $\begin{array}{c}\text { PA6 } \\
\text { (polyamide6) }\end{array}$ & $\begin{array}{c}\text { PA66 } \\
\text { (polyamide66) }\end{array}$ & $\begin{array}{c}\text { MXD6 } \\
\text { polyamide } \\
\text { MXD6) }\end{array}$ & $\begin{array}{c}\text { PAN } \\
\text { (Polyacrylo } \\
\text { nitrile) }\end{array}$ & $\begin{array}{c}\text { PES } \\
\text { (Polyether } \\
\text { sulfone) }\end{array}$ & $\begin{array}{c}\text { PolybMA } \\
\text { (Polydroxyethyl } \\
\text { methacrylate) }\end{array}$ & $\begin{array}{c}\text { PVA } \\
\text { (Polyvinyl } \\
\text { alcohol) }\end{array}$ \\
\hline$[\mathrm{Emim}][\mathrm{Ac}]$ & Soluble & Soluble & Soluble & - & Soluble & - & - \\
{$[\mathrm{Emim}][\mathrm{DEP}]$} & Soluble & Soluble & Soluble & - & - & - & - \\
{$[\mathrm{Emim}][\mathrm{Cl}]$} & - & - & - & Soluble & - & - & - \\
{$[\mathrm{Bmim}][\mathrm{Cl}]$} & Soluble & Soluble & Soluble & Soluble & - & Soluble & Soluble \\
{$[\mathrm{MeDBU}]\left[\mathrm{Me}_{2} \mathrm{PO}_{4}\right]$} & Soluble & Soluble & Soluble & - & Soluble & - & - \\
\hline
\end{tabular}

繊維束に加熱，加圧して含浸させてプリプレグを連続的 に作製する方法1)であり，通常は高粘度の樹脂が用いら れる。

その一方で，FRTP のプリプレグの製法は，熱可塑性 樹脂が溶剤には溶けにくいことから溶媒法によるプリプ レグ作製は困難であり，一般的には，繊維基材とシート 状に加工した高分子フィルムを積層して高温・高圧力で プレス成形する方法 ${ }^{3)}$ (以下，フィルムスタッキング法と 表記）が主に行われている. しかしながら，このフィル ムスタッキング法により溶融温度や溶融粘度が高い樹脂 を高含有率でプリプレグを作製する場合には，非常に高 い成形温度と圧力が必要であり多大なエネルギーと含浸 時間，そしてダブルベルトプレスマシン4)のような大型 で特殊な成形設備が必要となる。このため，より経済的 かつ効率的な FRTP のプリプレグおよびその作製方法 の開発が強く望まれている5).

最近, 熱可塑性樹脂の溶媒 ${ }^{6,7)}$ としてイオン液体 ${ }^{8)}$ が注 目を集めている. イオン液体は, 幅広い温度範囲で液体 として存在する塩であり, イオンからなる液体で, 蒸気 圧が低く, 難燃性であり, 熱安定性・電気化学的安定性 が高いことから, 従来の溶媒と比較して非常に安全で環 境への負荷も少ない。また, 電気伝導率が高く, 物質を よく溶かす ${ }^{9)}$ な゙, 他の化学物質にはない独自の興味深 い性質を持つことから，この 20 年ほどの間に様々な分 野で研究がされている ${ }^{10}$. このイオン液体を溶媒法によ るプリプレグ作製に用いることができれば，従来では困 難であった様々な熱可塑性樹脂をマトリックスとする FRTP のプリプレグが, 安全で環境への負荷が少なく, なおかつ経済的に作製できると期待される。しかしなが ら，イオン液体を用いた FRTP のプリプレグの作製に 関する研究は, これまで国内および海外においてもほと んどみられない.

そこで, 本研究では, イオン液体を溶媒とした溶媒法 によるFRTP のプリプレグの基本的な作製方法の提案
とそのプリプレグを用いて成形した FRTP の機械的特 性を調查することを目的とし, 代表的なイオン液体とし てイミダゾリウム塩系のイオン液体を用い, 熱可塑性樹 脂としてポリアミド樹脂とポリエーテルサルフォン樹脂 の 2 種類を選定し, 溶媒法によるFRTP のプリプレグ 作製を行った。特に, 熱可塑性樹脂をイオン液体一溶解 した際に樹脂の分子構造の変化が予想されるため, 熱可 塑性樹脂のイオン液体への溶解条件を変化させ, 作製し たプリプレグ中の樹脂の分子量や成形した FRTP の機 械的特性への影響を調查した。また, フィルムスタッキ ング法によるFRTP も同時に作製し, 本研究のイオン液 体を溶媒としたプリプレグを成形して得られた FRTP との機械的特性を比較, 評価を行い, その優位性につい て検証した。

\section{2. 供試材料およびプリプレグと FRTP の作製}

\section{1 供 試 材}

\subsection{1 イオン液体と熱可塑性樹脂の選定}

これまでの研究で明らかとなったイオン液体で溶解が 可能な熱可塑性樹脂を Table 1 亿示す $6,7,11)$. 本研究で は, Table 1 に示したイオン液体と熱可塑性樹脂の組み 合わせの中から, イオン液体としては, 非八ロゲン系か つ常温で低粘性液体であり, 工業的な生産が確立され比 較的安価に入手が可能なイミダゾリウム系イオン液体で ある 1-Ethyl-3-methylimidazolium acetate (Ionic Liquids Technologies GmbH 製; 以下 [Emim] [Ac] と表 記）を用い, 熱可塑性樹脂としてポリアミド樹脂(三菱ガ ス化学 (株) 製, MXD6ナイロンS6007; 以下 MXD6 と表記) とポリエーテルサルフォン樹脂（住友化学（株） 製, PES3600P ; 以下 PES と表記) の 2 種類を選定し, プリプレグの作製に使用した。 また，プリプレグに用い た強化纎維は, どちらの樹脂にもガラス繊維織物（日東 紡績（株）製，WEA22F-BX）を使用した。 


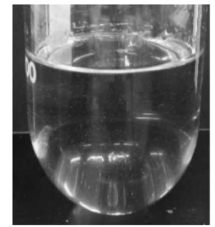

[E m i m ] [ A c ]

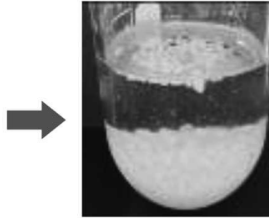

$[\mathrm{Em} \mathrm{im}][\mathrm{Ac}]+(\mathrm{M} X \mathrm{D} 6, \mathrm{PES})$

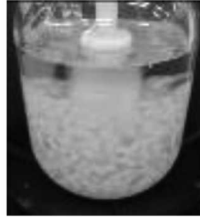

Stir

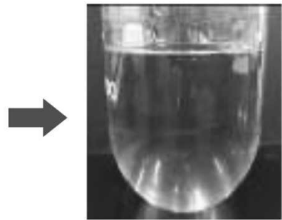

Solution

Fig. 1 Dissolution process of thermoplastic resins in ionic liquid.

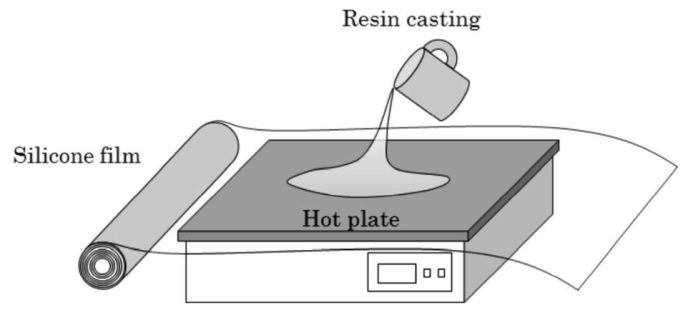

(1) Set the film to hot plate.
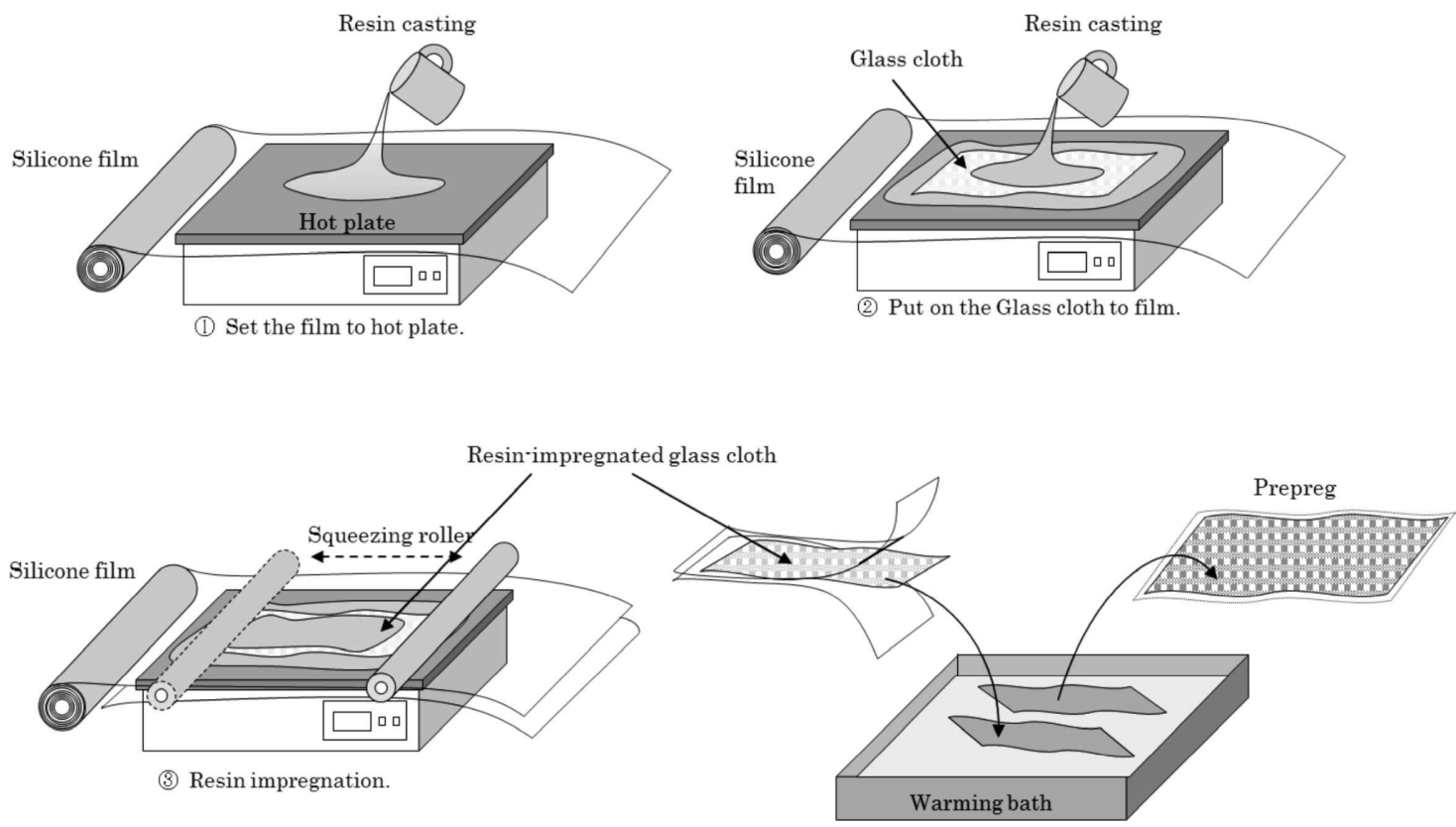

Fig. 2 Molding method of prepreg using ionic liquid.

\section{1 .2 熱可塑性樹脂のイオン液体への溶解}

MXD6 と PES の 2 種類の熱可塑性樹脂をそれぞれ $[\mathrm{Emim}][\mathrm{Ac}]$ へ溶解させ，熱可塑性樹脂の溶液を作製し た. 溶液中の樹脂の濃度は $20 \mathrm{wt} \%$ となるように調整し， 溶解温度を $40^{\circ} \mathrm{C}, 60^{\circ} \mathrm{C}, 80^{\circ} \mathrm{C}, 100^{\circ} \mathrm{C}, 120^{\circ} \mathrm{C}, 140^{\circ} \mathrm{C}$ 亿設 定して各温度で樹脂が完全に溶解するまで攪拌を続けた。 熱可塑性樹脂の $[\mathrm{Emim}][\mathrm{Ac}]$ への溶解プロセスを Fig. 1 亿示す.

なお，前章で述べたように熱可塑性樹脂をイオン液体 へ溶解させる段階で, 熱可塑性樹脂の分子構造が変化す る可能性が考えられる。このため, [Emim] [Ac] の分解 温度 $\left(150^{\circ} \mathrm{C}\right)$ 以下で, MXD6 と $\mathrm{PES}$ の 2 種類の熱可塑 性樹脂を溶解したプリプレグの作製を行うための溶液 （以下，プリプレグ溶液と表記）の分子量分布を計測し， 溶解条件が分子構造へ与える影響について調查を行っ た。詳細な計測条件に関しては，3.1 節で述べる。

\subsection{3 プリプレグの作製方法}

本研究で用いたプリプレグの作製方法の概要を Fig. 2 に示す. 本研究では, 繊維織物基材へのプリプレグ溶液 の含浸性を向上させる目的で, プリプレグ溶液を [Emim] $[\mathrm{Ac}]$ の分解温度 $\left(150^{\circ} \mathrm{C}\right)$ 以下である $100^{\circ} \mathrm{C}$ に加熱して粘 性を低下させ，同じく $100^{\circ} \mathrm{C}$ に加熱した平板形状の金型 の上で HLU 法にてガラス繊維織物にプリプレグ溶液を 含浸させた。次に, [Emim] [Ac] を除去するため $60^{\circ} \mathrm{C}$ の

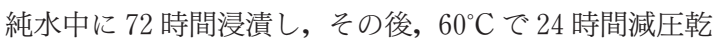
燥を行い, $300 \times 300 \mathrm{~mm}$ の寸法のプリプレグを作製し た。

\subsubsection{FRTP の作製方法}

前項 2.1.3 で作製したプリプレグを 5 枚重ねて, 平板形 状の金型を用いてプレス成形により FRTP を作製した。 また，特性比較のため, $0.1 \mathrm{~mm}$ 厚みの MXD6 と PES の シートフィルムとガラス繊維織物を交互に 5 枚積層し 


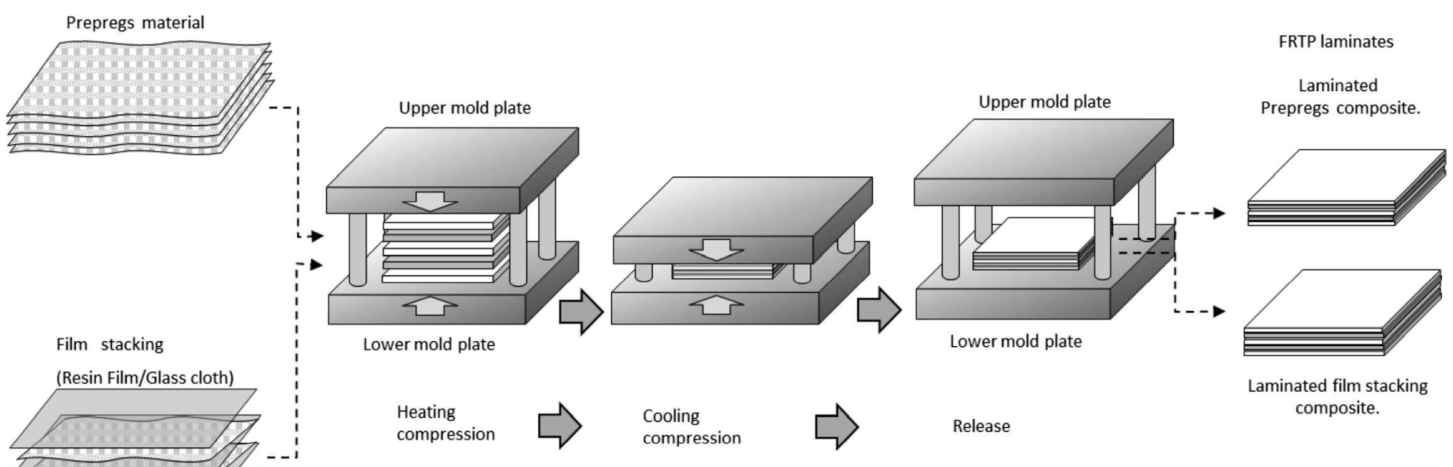

Fig. 3 Schematic of press molding method.

Table 2 Molding condition of FRTP

\begin{tabular}{lcc}
\hline \hline & MXD6 & PES \\
\hline Heating temperature $\left({ }^{\circ} \mathrm{C}\right)$ & 270 & 340 \\
Heating time (min) & 5 & 5 \\
Molding pressure $(\mathrm{MPa})$ & 1.0 & 1.0 \\
Cooling rate to room temperature & 25 & 25 \\
$\left({ }^{\circ} \mathrm{C} / \mathrm{min}\right)$ & & \\
\hline
\end{tabular}

て，同じ金型とプレスを用いてフィルムスタッキング法 にて FRTPを作製した。このプレス成形の概要を Fig. 3 に示し, プレス成形条件を Table 2 に示す. FRTP の仕 上がり寸法と繊維体積含有率 $V_{\mathrm{f}}$ は，すべての FRTP で 同じになるように金型のクリアランスを調整すること で, 幅 $300 \mathrm{~mm}$, 長さ $300 \mathrm{~mm}$, 厚さ $1.05 \mathrm{~mm}$ で繊維体積 含有率 $V_{\mathrm{f}}$ は $40 \%$ となった。

\section{3. 実 験 方 法}

\section{1 平均分子量および分子量分布の測定}

前章で述べたように熱可塑性樹脂をイオン液体へ溶解 させる段階で, 熱可塑性樹脂の分子構造が変化する可能 性が考えられる。このため, [Emim][Ac] 亿溶解する前の 樹脂 (以下 NR と表記) と，前章の 2.1.3で作製したプリ プレグ中の樹脂(以下 $\mathrm{CR}$ と表記), そして前章の 2.1.4 で プレス成形して得られた FRTP 中に含まれる樹脂 (以下 MR と表記) の合計 3 段階の樹脂について, それぞれ平均 分子量と分子量分布の測定を行った。

平均分子量と分子量分布は, JIS-K7252 に準じてゲル 浸透クロマトグラフィー (以下 GPC と表記) により測定 を行い，重量平均分子量 (weight average molecular weight, 以下 $M_{\mathrm{w}}$ と表記), 数平均分子量 (以下 $M_{\mathrm{n}}$ と表
記) および多分散度 (以下 PD と表記) を求めた。本 GPC で用いたクロマトグラフの条件と溶離液を樹脂ごとに Table 3 にまとめて示す.

本 GPC 測定では, 樹脂を溶離液へ溶解させた後, 未溶 解物を取り除くために $0.2 \mu$ メッシュのメンブレンフィ ルターでろ過を行ってから, クロマトグラフへ注入して 測定を行った。また，本 GPC 測定に用いた標準試料は， 溶媒への溶解性の観点から, MXD6 ではポリメチルメ夕 クリレートを, PES ではポリエチレンオキサイドとポリ エチレングリコールを標準試料として選定した。

\section{2 走查型電子顕微鏡 $(\mathrm{SEM})$ 観察}

作製した FRTP の含浸状態を評価するために, 走査型 電子顕微鏡（SEM）による断面観察を行った. SEM 観 察試験片は, 成形板から切断した後, 予め耐水研磨紙 (\#4000 番) で研磨後, シリカ研磨液にて鏡面仕上げを行 い, 観察面に付着した研磨剤 (污染物) を純水中で超音 波により洗浄した。その後, $60^{\circ} \mathrm{C} て ゙ 2$ 時間乾燥させ, 観 察面に $\mathrm{Au}$ を $10 \mathrm{~nm}$ 程度蒸着した. SEM 観察は, 走査型 電子顕微鏡（(株) 日立八イテクノロジーズ製 S- $3400 \mathrm{~N})$ を使用して真空減圧下にて断面観察および撮影を行っ た。さらに, FRTP の強化繊維と樹脂との接着状態を評 価するために, 曲げ破断部の SEM 観察も行った。

\subsection{3 点曲げ試験}

本研究の FRTP と比較のためフィルムスタッキング 法にて成形したFRTP との強度および弾性率を比較, 評 価するために，JIS K 7017 に準じた 3 点曲げ試験による 強度，弾性率の測定を行った。試験片のサイズは，厚さ $t=1.05 \mathrm{~mm}$, 幅 $b=15 \mathrm{~mm}$, 長さ $l=100 \mathrm{~mm}$ で曲げスパ

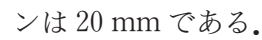


Table 3 Conditions for chromatograph measurement.

\begin{tabular}{lcc}
\hline \hline & MXD6 & PES \\
\hline $\begin{array}{l}\text { Detector } \\
\text { Columns }\end{array}$ & Refractive index & Refractive index \\
& Shodex LF-404 $\times 2$ & Shodex KD-806M $\times 2$ \\
& & KD-802 \\
Columns temperature & $40^{\circ} \mathrm{C}$ & $\mathrm{KD}-\mathrm{G}$ \\
Eluting solution & Hexafluoroisopropyl alcohol & $N, N$-dimethylformamide \\
& $*$ Trifluoroacetic acid sodium salt; & $*$ Lithium bromide; \\
& $5 \mathrm{mmol} / \mathrm{L}$ & $10 \mathrm{mmol} / \mathrm{L}$ \\
Flow rate & $0.3 \mathrm{~mL} / \mathrm{min}$ & $1.0 \mathrm{~mL} / \mathrm{min}$ \\
Sample concentration & $0.1 \mathrm{w} / \mathrm{v} \%$ & $0.2 \mathrm{w} / \mathrm{v} \%$ \\
Injection volume & $10 \mu \mathrm{L}$ & $100 \mu \mathrm{L}$ \\
\hline
\end{tabular}

Table 4 Dissolution condition of MXD6 in ionic liquid.

\begin{tabular}{cccccccc}
\hline \hline & & \multicolumn{5}{c}{ Dissolution temperature $\left({ }^{\circ} \mathrm{C}\right)$} \\
\cline { 3 - 7 } & & 40 & 60 & 80 & 100 & 120 & 140 \\
\hline & 3 & unsoluble & unsoluble & unsoluble & unsoluble & unsoluble & soluble \\
Stirring time & 9 & unsoluble & unsoluble & unsoluble & unsoluble & soluble & - \\
(hr) & 12 & unsoluble & unsoluble & unsoluble & soluble & - & - \\
& 24 & unsoluble & soluble & - & - & - & - \\
& 48 & soluble & - & - & - & - & - \\
& 72 & - & - & - & - & - & - \\
\hline
\end{tabular}

Table 5 Dissolution condition of PES in ionic liquid.

\begin{tabular}{cccccccc}
\hline \hline & & \multicolumn{5}{c}{ Dissolution temperature $\left({ }^{\circ} \mathrm{C}\right)$} \\
\cline { 2 - 7 } & 3 & unsoluble & unsoluble & unsoluble & unsoluble & unsoluble & soluble \\
& 6 & unsoluble & unsoluble & unsoluble & unsoluble & soluble & - \\
Stirring time & 9 & unsoluble & unsoluble & unsoluble & soluble & - & - \\
(hr) & 12 & unsoluble & unsoluble & soluble & - & - & - \\
& 24 & unsoluble & unsoluble & - & - & - & - \\
& 48 & unsoluble & soluble & - & - & - & - \\
\hline
\end{tabular}

\section{4 動的粘弾性試験}

本研究の FRTP と比較のためフィルムスタッキング 法にて成形したFRTP との動的粘弾性を評価するため に, JIS K7244-5 に準じた動的粘弾性試験を行った。試 験片形状は, 厚み $h=1.05 \mathrm{~mm}$, 幅 $b=10 \mathrm{~mm}$, 長さ $l=$ $50 \mathrm{~mm}$ である。試験機は動的粘弾性測定機 DMS-6100 (セイコーインスツルメンツ製)を用い，両端部を完全固 定とし, 試料中央部を $5 \mathrm{~mm}$ 幅でクランプし曲げによる 正弦的ひずみを加えた. 試験条件は, 測定温度 $T=20$ $300^{\circ} \mathrm{C}$ とし, 昇温速度を $2^{\circ} \mathrm{C} / \mathrm{min}$, 加振周波数は $1 \mathrm{~Hz}$ で 測定を行った。

\section{4. 実験結果と考察}

\section{1 繊維強化熱可塑性樹脂プリプレグの作製結果}

Fig. 1 で示した溶解プロセスにより溶解させたプリプ レグ溶液の状態を各溶解温度，攪汼時間ごとに Table 4 と Table 5 に示す。これらの表から明らかなように，本 溶解条件においては，MXD6, $\mathrm{PES}$ ともに各々 $40^{\circ} \mathrm{C} 48$ 時間, $40^{\circ} \mathrm{C} 72$ 時間の条件で完全に溶解したプリプレグ 溶液が得られた. Fig. 4 に, Table 4 , Table 5 の溶解条 件で作製したプリプレグ溶液の粘度曲線を示す。この図 からも明らかなように，溶液を $60^{\circ} \mathrm{C}$ 以上に加熱するこ 


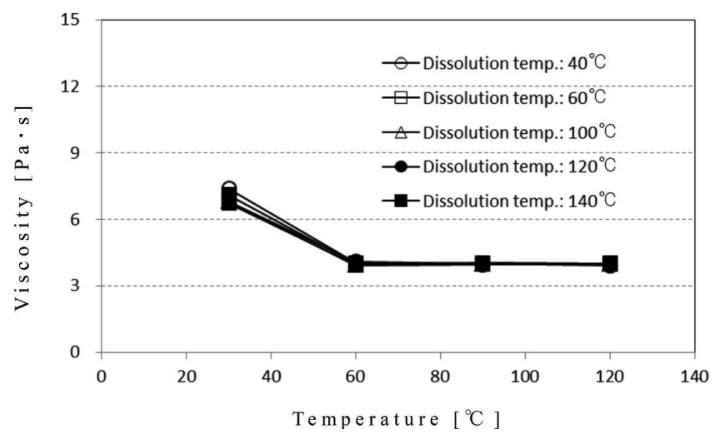

(a) MXD6

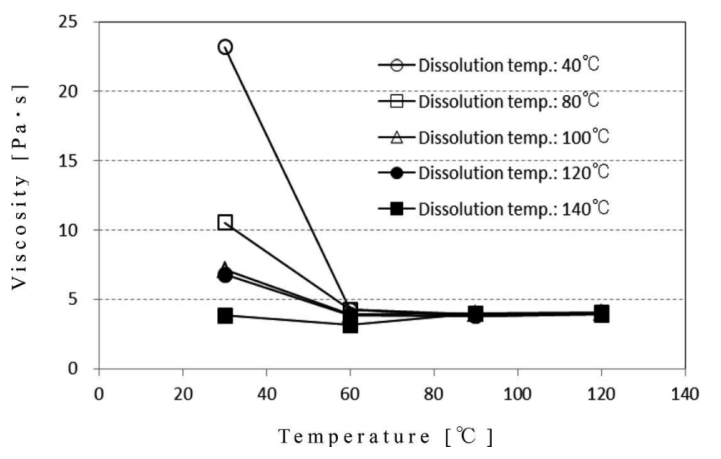

(b) PES

Fig. 4 Viscosity curves of thermoplastic dissolved in ionic liquid.

Table 6 Molecular weight of CR and NR for each dissolution conditions.

\begin{tabular}{|c|c|c|c|c|c|c|c|c|c|c|c|c|}
\hline & & \multicolumn{10}{|c|}{$\begin{array}{l}\text { CR (Coagulation resin) } \\
\text { Dissolution condition; Temperature/Stirring time }\end{array}$} & \multirow{2}{*}{$\begin{array}{l}\text { NR } \\
\text { (Neat } \\
\text { resin) }\end{array}$} \\
\hline & & $\begin{array}{l}40^{\circ} \mathrm{C} / \\
48 \mathrm{hr}\end{array}$ & $\begin{array}{l}40^{\circ} \mathrm{C} / \\
72 \mathrm{hr}\end{array}$ & $\begin{array}{l}60^{\circ} \mathrm{C} / \\
24 \mathrm{hr}\end{array}$ & $\begin{array}{l}60^{\circ} \mathrm{C} / \\
48 \mathrm{hr}\end{array}$ & $\begin{array}{l}80^{\circ} \mathrm{C} / \\
12 \mathrm{hr}\end{array}$ & $\begin{array}{c}100^{\circ} \mathrm{C} / \\
9 \mathrm{hr}\end{array}$ & $\begin{array}{l}120^{\circ} \mathrm{C} / \\
6 \mathrm{hr}\end{array}$ & $\begin{array}{l}140^{\circ} \mathrm{C} / \\
3 \mathrm{hr}\end{array}$ & $\begin{array}{l}140^{\circ} \mathrm{C} / \\
48 \mathrm{hr}\end{array}$ & $\begin{array}{l}140^{\circ} \mathrm{C} / \\
72 \mathrm{hr}\end{array}$ & \\
\hline \multirow{3}{*}{ MXD6 } & $M_{\mathrm{w}}$ & 81,000 & - & 75,200 & - & 79,300 & 79,900 & 80,800 & 79,800 & 62,000 & 56,500 & 82,900 \\
\hline & $M_{\mathrm{n}}$ & 44,000 & - & 38,800 & - & 44,000 & 44,000 & 45,100 & 44,200 & 35,700 & 32,900 & 45,500 \\
\hline & $\mathrm{PD}$ & 1.8 & - & 1.9 & - & 1.8 & 1.8 & 1.8 & 1.8 & 1.7 & 1.7 & 1.8 \\
\hline \multirow{3}{*}{ PES } & $M_{\mathrm{w}}$ & - & 26,100 & - & 25,800 & 24,400 & 18,700 & 10,300 & 6,100 & - & - & 27,000 \\
\hline & $M_{\mathrm{n}}$ & - & 11,300 & - & 11,600 & 11,000 & 8,600 & 5,000 & 2,900 & - & - & 11,700 \\
\hline & $\mathrm{PD}$ & - & 2.3 & - & 2.2 & 2.2 & 2.2 & 2.1 & 2.1 & - & - & 2.3 \\
\hline
\end{tabular}

とで粘度が $5 \mathrm{~Pa} \cdot \mathrm{s}$ 程度まで低下することが確認できる。 また，本研究のプリプレグ作製において，MXD6のプ リプレグ溶液の全てでプリプレグを作製することができ

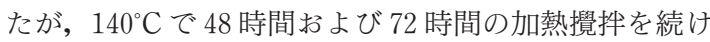
たプリプレグ溶液を用いて作製したプリプレグには，茶 色の着色がみられた。一方, PES においては， $100^{\circ} \mathrm{C}$ 以 下の条件で溶解した溶液ではプリプレグを問題なく作製 することができたが, $120^{\circ} \mathrm{C}$ およ゙ $140^{\circ} \mathrm{C}$ の条件で溶解 したプリプレグ溶液を用いてプリプレグの作製を試みた ところ, 純水中へ浸漬した段階でガラスクロス上から樹 脂が脱落してしまいプリプレグを作製することができな かった。

\section{2 溶解条件による熱可塑性樹脂の分子量と分子量 分布への影響}

本研究の異なる溶解条件で作製した CR と NRの $M_{\mathrm{w}}$, $M_{\mathrm{n}}$ および PD を Table 6, 分子量分布曲線を Fig. 5 に示 す.また，本研究の FRTP と比較のためフィルムスタッ キング法にて作製した FRTP 中の MRの $M_{\mathrm{w}} ， M_{\mathrm{n}}$ およ びPDを Table 7 に示す.

Table 6 から, 溶解条件によって MXD6, PES ともに
$M_{\mathrm{w}}$ と $M_{\mathrm{n}}$ が変化していることがわかる.MXD6 では， 溶解条件が $40^{\circ} \mathrm{C} / 48 \mathrm{hr}, 60^{\circ} \mathrm{C} / 24 \mathrm{hr}, 80^{\circ} \mathrm{C} / 12 \mathrm{hr}, 100^{\circ} \mathrm{C} /$ $8 \mathrm{hr}, 120^{\circ} \mathrm{C} / 6 \mathrm{hr}, 140^{\circ} \mathrm{C} / 3 \mathrm{hr}$ の CR は, NR とほぼ同レ ベルの $M_{\mathrm{w}}$ と $M_{\mathrm{n}}$ であり, これらの溶解条件であれば $[\mathrm{Emim}][\mathrm{Ac}]$ 一溶解させても樹脂の分子構造は変化し なかったと考えられる。しかし, 溶解条件が $140^{\circ} \mathrm{C} / 48$ $\mathrm{hr}, 140^{\circ} \mathrm{C} / 72 \mathrm{hr}$ の CR は, NR と比較して $25 \%$ から $30 \%$ ほど $M_{\mathrm{w}}$ および $M_{\mathrm{n}}$ が低下しており, 溶解温度が高く, 溶解時間も長い場合では分子構造が変化してしまうこと がわかった。

一方 PES では, 溶解条件が $40^{\circ} \mathrm{C} / 72 \mathrm{hr}, 60^{\circ} \mathrm{C} / 48 \mathrm{hr}$, $80^{\circ} \mathrm{C} / 12 \mathrm{hr}$ の CR は, NR とほほ同レベルの $M_{\mathrm{w}}$ と $M_{\mathrm{n}}$ であったが, 溶解条件が $100^{\circ} \mathrm{C} / 9 \mathrm{hr}, 120^{\circ} \mathrm{C} / 6 \mathrm{hr}, 140^{\circ} \mathrm{C} /$ $3 \mathrm{hr}$ の CR は, NR と比較して $30 \%$ から $70 \%$ ほど $M_{\mathrm{w}}$ お よび $M_{\mathrm{n}}$ が低下しており, MXD6よりも低い溶解温度お よび短時間で分子構造が変化していることがわかる。ま た, MXD6 およびPES ともに CR の PD は, 溶解条件 によらずほぼ一定であり, それぞれの NR とほぼ同じ值 であることもわかった. $M_{\mathrm{W}}$ および $M_{\mathrm{n}}$ が変化しても $\mathrm{PD}$ が変化していないことから, 本研究の溶解条件では, 樹 


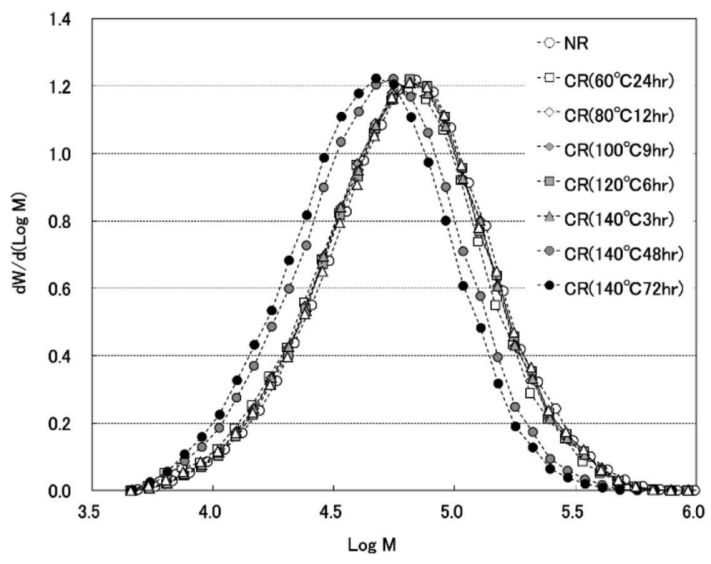

(a) MXD6

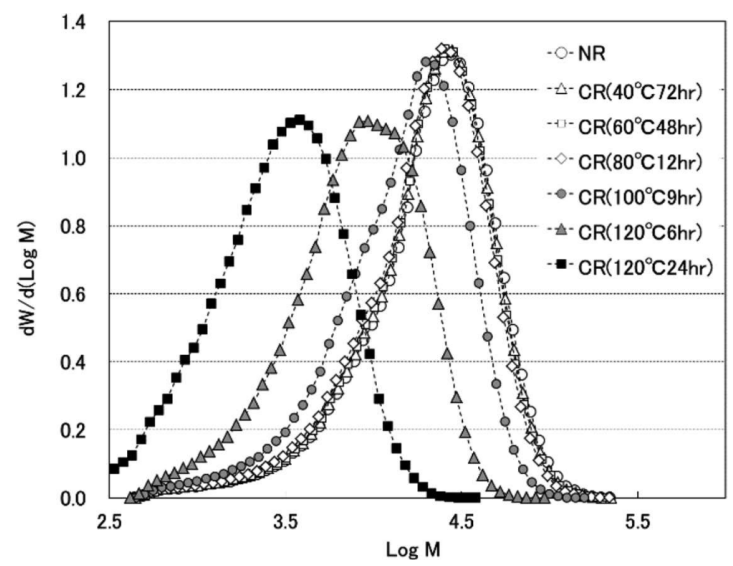

(b) PES

Fig. 5 Molecular weight distribution of CR and NR for each dissolution conditions.

Table 7 Molecular weight of MR for each dissolution conditions.

\begin{tabular}{cccccccccccccc}
\hline \hline & \multicolumn{10}{c}{ MR (Molded resin) } & & NR \\
& & \multicolumn{10}{c}{ Dissolution condition; Temperature/Stirring time } & & (Neat \\
& & $40^{\circ} \mathrm{C} /$ & $40^{\circ} \mathrm{C} /$ & $60^{\circ} \mathrm{C} /$ & $60^{\circ} \mathrm{C} /$ & $80^{\circ} \mathrm{C} /$ & $100^{\circ} \mathrm{C} /$ & $120^{\circ} \mathrm{C} /$ & $140^{\circ} \mathrm{C} /$ & $140^{\circ} \mathrm{C} /$ & $140^{\circ} \mathrm{C} /$ & resin) \\
& $48 \mathrm{hr}$ & $72 \mathrm{hr}$ & $24 \mathrm{hr}$ & $48 \mathrm{hr}$ & $12 \mathrm{hr}$ & $9 \mathrm{hr}$ & $6 \mathrm{hr}$ & $3 \mathrm{hr}$ & $48 \mathrm{hr}$ & $72 \mathrm{hr}$ & \\
\hline \multirow{3}{*}{ MXD6 } & $M_{\mathrm{w}}$ & 52,500 & - & 53,000 & - & 59,600 & 58,900 & 69,200 & 67,600 & 55,100 & 45,700 & 62,900 \\
& $M_{\mathrm{n}}$ & 25,300 & - & 25,800 & - & 29,200 & 28,500 & 35,800 & 33,300 & 29,400 & 24,800 & 33,700 \\
& $M_{\mathrm{w}}$ & 2.1 & - & 2.1 & - & 2.0 & 2.1 & 1.9 & 2.0 & 1.9 & 1.8 & 1.9 \\
\hline \multirow{3}{*}{$\mathrm{PES}$} & $M_{\mathrm{w}}$ & - & 25,100 & - & 25,600 & 24,400 & 18,700 & - & - & - & - & 25,800 \\
& $M_{\mathrm{n}}$ & - & 10,800 & - & 10,800 & 10,700 & 8,500 & - & - & - & - & 11,000 \\
& $\mathrm{PD}$ & - & 2.3 & - & 2.4 & 2.3 & 2.2 & - & - & - & - & 2.3 \\
\hline
\end{tabular}

脂の分子量分布（分散）は変化せず，構成する分子鎖そ れぞれが平均的に小さくなったものと考元られる。

Fig. 5 に示したように, MXD6 では, 溶解条件が $140^{\circ}$ $\mathrm{C} / 48 \mathrm{hr}, 140^{\circ} \mathrm{C} / 72 \mathrm{hr}$ の CR の分子量分布曲線は，他の 溶解条件の $\mathrm{CR}$ および NR の分子量分布曲線よりも若 干低分子量側にシフトしていることがわかる.しかし， 分子量分布曲線の形は，ほぼ同じであり，このことから も選択性なく全体的に分子が小さくなっていたことがわ かる.

一方, PES では, 溶解条件が $100^{\circ} \mathrm{C} / 9 \mathrm{hr}$ の CR の分子 量分布曲線は, NR の分子量分布曲線に対してピークト ップが低分子量側へ若干シフトしているだけなのに対 し, $120^{\circ} \mathrm{C} / 6 \mathrm{hr}, 140^{\circ} \mathrm{C} / 3 \mathrm{hr}$ の CR の分子量分布曲線は, 全体的に低分子量側へシフトし，さらに低分子量体の増 加とピークトップ位置が低下している.このことからも， PES は MXD6よりも [Emim] [Ac] で溶解した際に低 分子量化しやすく, 溶解条件によっては分子量分布が変
化してしまうことがわかった。

また, Table 7 から, 本研究のプリプレグを用いた FRTP拉よびフィルムスタッキング法で作製した FRTP の MR の $M_{\mathrm{w}}, M_{\mathrm{n}}$ および PD は, それぞれ同じ溶 解条件で作製した $\mathrm{CR}$ や $\mathrm{NR}$ とほぼ同じであったこと がわかる.このことから, 本研究の成形条件では, FRTP 中の樹脂の分子構造は変化しておらず，プリプレグおよ びフィルムの樹脂の分子構造と同様であったと考えられ る.

\section{3 走査型電子顕微鏡（SEM）による観察}

作製した FRTP の試験片の断面写真を Fig. 6 および Fig. 7 に示す. 本研究のプリプレグを用いて作製した FRTPすべての試験片の断面観察において，マトリック スである樹脂がほぼ均質に強化繊維束に含浸しており, ボイド等の欠陥は観察されなかった。一方, フィルムス タッキング法で作製した FRTP の試験片の断面を観察 したところ, 強化繊維束の内部に空隙がわずかにみら 


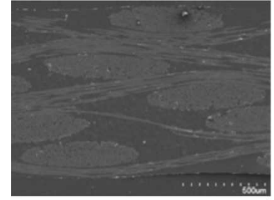

$40{ }^{\circ} \mathrm{C} / 48 \mathrm{~h} \mathrm{r}$

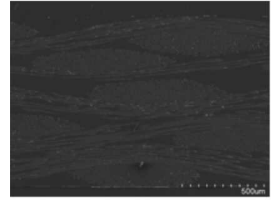

$100{ }^{\circ} \mathrm{C} / 9 \mathrm{~h} \mathrm{r}$

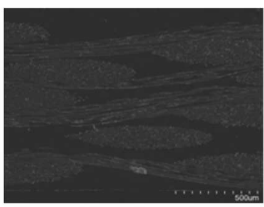

$140{ }^{\circ} \mathrm{C} / 48 \mathrm{hr}$

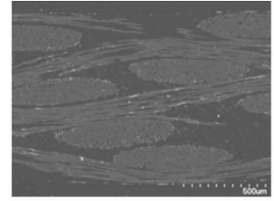

$60^{\circ} \mathrm{C} / 28 \mathrm{hr}$

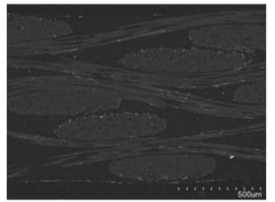

$120^{\circ} \mathrm{C} / 6 \mathrm{~h} \mathrm{r}$

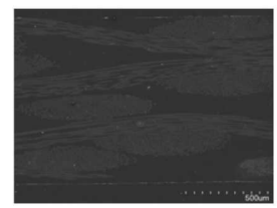

$140{ }^{\circ} \mathrm{C} / 72 \mathrm{hr}$

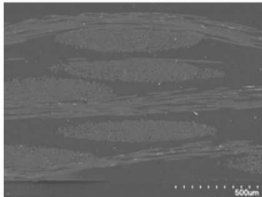

$80{ }^{\circ} \mathrm{C} / 12 \mathrm{~h} \mathrm{r}$

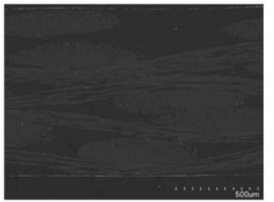

$140{ }^{\circ} \mathrm{C} / 3 \mathrm{hr}$

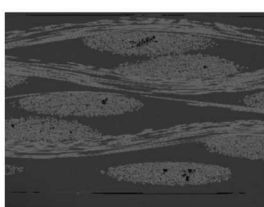

Film stacking

Fig. 6 Cross-sectional SEM photographs of FRTP specimen with MXD6 as a matrix.

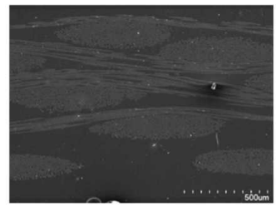

$40{ }^{\circ} \mathrm{C} / 72 \mathrm{~h} \mathrm{r}$

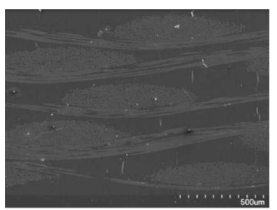

$80{ }^{\circ} \mathrm{C} / 12 \mathrm{hr}$

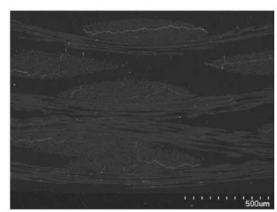

$100{ }^{\circ} \mathrm{C} / 9 \mathrm{hr}$

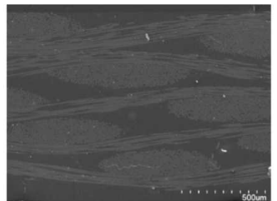

$60{ }^{\circ} \mathrm{C} / 48 \mathrm{hr}$

Fig. 7 Cross-sectional SEM photographs of FRTP specimen with PES as a matrix.

れ，本研究の成形条件では樹脂が含浸しきれていなかつ たことがわかった。

本研究のプリプレグは, 樹脂がイオン液体で溶解され 粘度の低い液状の状態で補強繊維へ含浸するため, クロ ス基材のような強化繊維の含有率が高い長繊維基材にお いても良好な含浸状態が得られると考えられる.このこ とから，イオン液体を用いて溶媒法で作製したプリプレ グを中間材料として成形する FRTP の作製方法は, フィ
ルムスタッキング法による FRTP の作製方法と比較し て, より低エネルギーで簡易的に成形が可能であると期 待される。

\subsection{3 点曲げ試験}

本研究のプリプレグを用いて作製した FRTP と比較 のためにフィルムスタッキング法にて作製した FRTP の常温での 3 点曲げ試験の結果を Fig. 8 に示す.この図 から，MXD6 の溶解条件が $40^{\circ} \mathrm{C} / 72 \mathrm{hr}, 60^{\circ} \mathrm{C} / 48 \mathrm{hr}, 80$ 


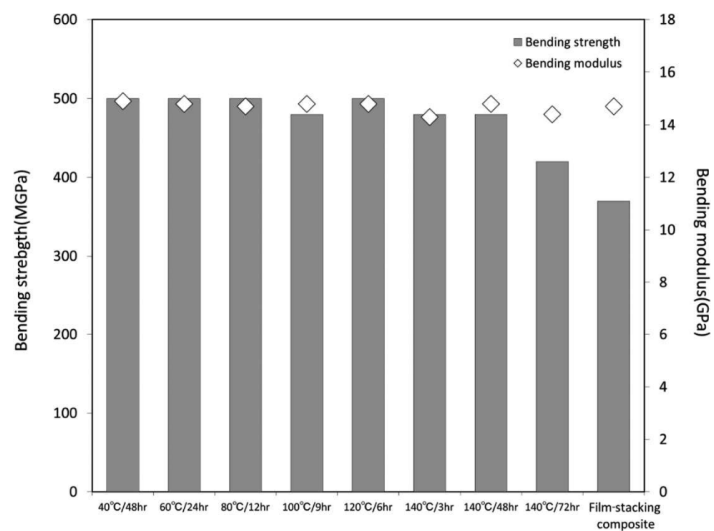

(a) MXD6

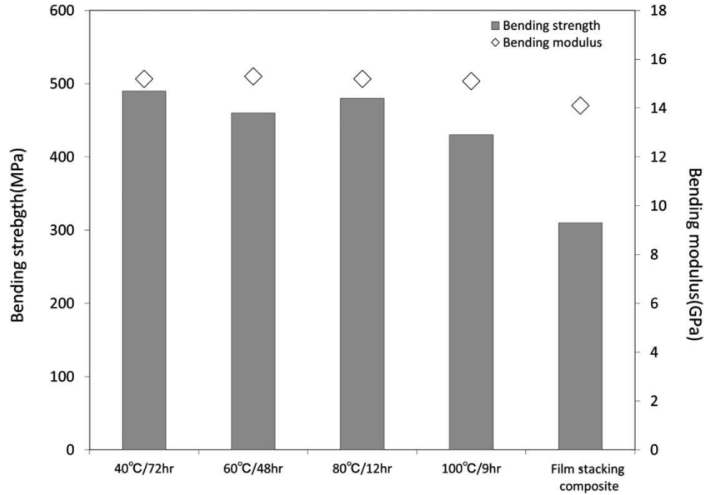

(b) PES

Fig. 8 Results of bending test of FRTP at various dissolution conditions.

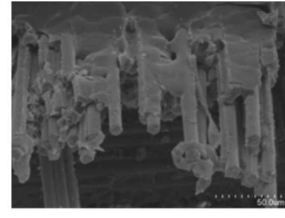

$40{ }^{\circ} \mathrm{C} / 48 \mathrm{~h} \mathrm{r}$

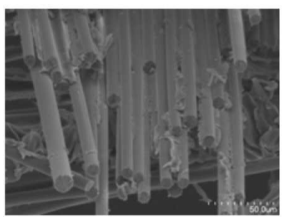

$100{ }^{\circ} \mathrm{C} / 9 \mathrm{~h} \mathrm{r}$

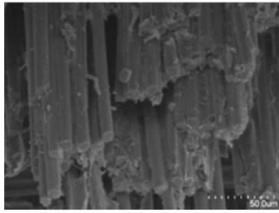

$140{ }^{\circ} \mathrm{C} / 48 \mathrm{hr}$

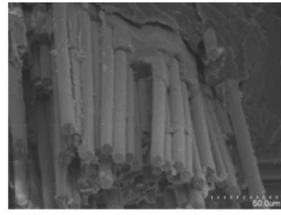

$60{ }^{\circ} \mathrm{C} / 24 \mathrm{hr}$

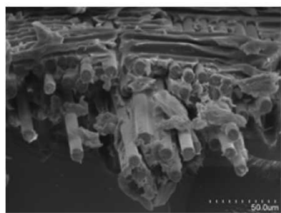

$120{ }^{\circ} \mathrm{C} / 6 \mathrm{~h} \mathrm{r}$

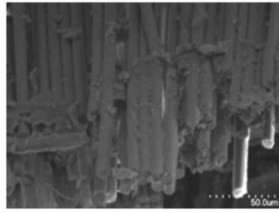

$140{ }^{\circ} \mathrm{C} / 72 \mathrm{~h} \mathrm{r}$

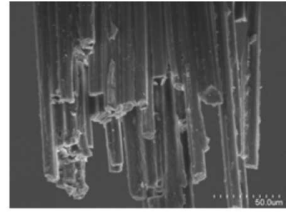

$80{ }^{\circ} \mathrm{C} / 12 \mathrm{~h} \mathrm{r}$

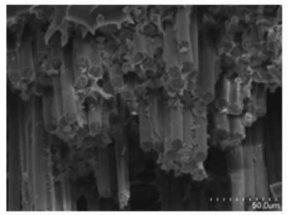

$140{ }^{\circ} \mathrm{C} / 3 \mathrm{~h} \mathrm{r}$

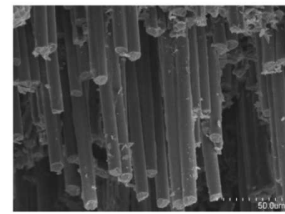

Fil m stacking

Fig. 9 Fracture surface of FRTP specimen with MXD6 as a matrix after three point bending tests.

${ }^{\circ} \mathrm{C} / 12 \mathrm{hr}, 100^{\circ} \mathrm{C} / 8 \mathrm{hr}, 120^{\circ} \mathrm{C} / 6 \mathrm{hr}, 140^{\circ} \mathrm{C} / 3 \mathrm{hr}, 140^{\circ} \mathrm{C} /$ $48 \mathrm{hr}$ であった本研究のプリプレグを用いた FRTP は, すべてほぼ同様の曲げ強さを示し，フィルムスタッキン グ法で作製した FRTP と比較して, 強度が 2 割ほど高い ことがわかる。しかし, MXD6 の溶解条件が $140^{\circ} \mathrm{C} / 72 \mathrm{hr}$ であった本研究のプリプレグを用いた FRTP は, 他の溶 解条件で作製したプリプレグを用いた FRTP と比較し て 1 割ほど強度が低く, 十分な強度が得られていない。
次に, PES の溶解条件が $40^{\circ} \mathrm{C} / 72 \mathrm{hr}, 60^{\circ} \mathrm{C} / 48 \mathrm{hr}$, $80^{\circ} \mathrm{C} / 12 \mathrm{hr}$ の本研究のプリプレグを用いた FRTP は, ほぼ同様の曲げ強さを示し，フィルムスタッキング法で 作製した FRTP と比較して, 強度が 3 割ほど高い. しか し, 溶解条件が $100^{\circ} \mathrm{C} / 9 \mathrm{hr}$ であった本研究のプリプレグ を用いた FRTP は, 他の溶解条件のプリプレグを用いた FRTP と比較すると強度が若干低く, 十分な強度が得ら れていない。 


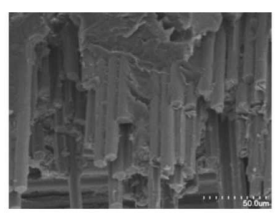

$40{ }^{\circ} \mathrm{C} / 72 \mathrm{~h} \mathrm{r}$

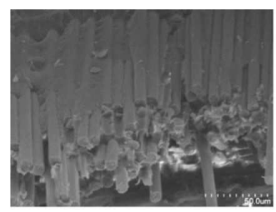

$60^{\circ} \mathrm{C} / 48 \mathrm{~h} \mathrm{r}$

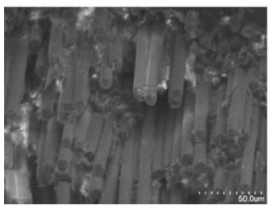

$80{ }^{\circ} \mathrm{C} / 12 \mathrm{~h} \mathrm{r}$

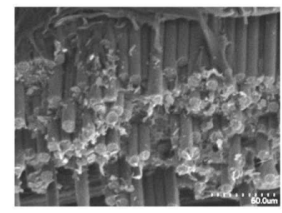

$100{ }^{\circ} \mathrm{C} / 9 \mathrm{hr}$

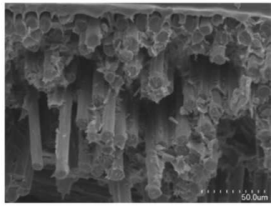

Film stacking

Fig. 10 Fracture surface of FRTP specimen with PES as a matrix after three point bending tests.

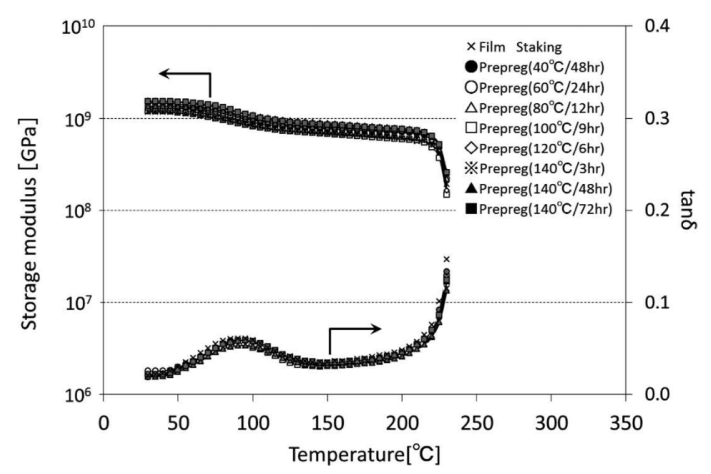

(a) MXD6

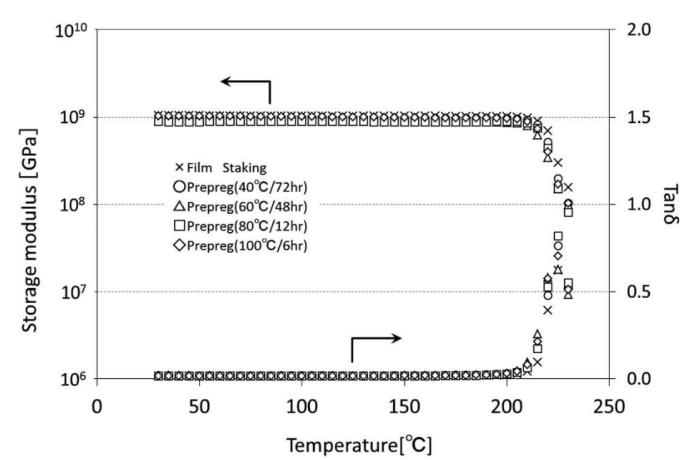

(b) PES

Fig. 11 Dynamic viscoelasticity of FRTP at various dissolution conditions.

この理由として, 本研究のプリプレグを用いた FRTP は，樹脂がイオン液体で溶解され粘度の低い液状の状態 で補強繊維へ含浸するため, 補強繊維の表面と濡れやす く, 繊維と樹脂との界面特性がフィルムスタッキング法 で作製したFRTPよりも良好だったためと推察される. また， $140^{\circ} \mathrm{C} / 72 \mathrm{hr}$ で溶解した MXD6 のプリプレグや $100^{\circ} \mathrm{C} / 9 \mathrm{hr}$ で溶解したPES のプリプレグを用いた FRTP は, 樹脂が低分子量化してしまったため, FRTP の強度 低下を引き起こしたのではないかと考えられる。

曲げ試験後の各試験片の破断面の SEM 観察写真を Fig. 9 および Fig. 10 に示す. 本研究のプリプレグを用い たFRTPは, 樹脂が繊維表面に多数付着しており, 繊維 と樹脂との接着状態が良好であったものと推察される. また,フィルムスタッキング法で作製した FRTP の破断 面は, 補強繊維から樹脂が剥離して滑らかな䋊維表面が 観察され, 樹脂と䋊維との接着状態が悪かったと推察さ
れる.これらの曲げ強度のデータおよび破断面の SEM 観察から, 本研究のプリプレグを用いた FRTP の作製方 法は, FRTP の機械的特性の向上に有効であるといえる.

\section{5 動的粘弾性試験}

本研究のプリプレグを用いて作製した FRTP と比較 のためにフィルムスタッキング法にて作製した FRTP の動的粘弾性の試験の結果を Fig. 11 に示す.

Fig. 11 から, MXD6 をマトリックスとした本研究の プリプレグを用いて作製した FRTP とフィルムスタッ キング法で作製した FRTP の動的粘弾性試験から得ら れた結果はほぼ同じであることがわかる.MXD6をマト リックスとしたFRTPのすべての試験片において, MXD6 のガラス転移温度 $\left(T_{\mathrm{g}} 80 \sim 90^{\circ} \mathrm{C}\right)$ から $200^{\circ} \mathrm{C}$ まで の温度域であれば顕著な弾性率の低下はみられず, MXD6 の融点 $\left(T_{\mathrm{m}} 230^{\circ} \mathrm{C}\right)$ 付近の温度域で弾性率が急激 に低下することがわかる。このことから，結晶性ポリマ 
ーであるMXD6 は，分子鎖が結晶部分で拘束されてい るため, 融点付近まで高い剛性を維持することが可能で あり，高い耐熱性を有したFRTPとして使用できる可 能性がある。

一方, PES をマトリックスとした本研究のプリプレグ を用いて作製した FRTP とフィルムスタッキング法で 作製したFRTP の動的粘弾性の試験結果はほぼ同じで あり，すべての試験片において PESのガラス転移温度 $\left(T_{\mathrm{g}} 225^{\circ} \mathrm{C}\right)$ を超えたところで弾性率が急激に低下するこ とがわかる.PES は透明な非晶性ポリマーであるが分子 鎖の強い分子間相互作用によって高いガラス転移温度を 有している。このため, $200^{\circ} \mathrm{C}$ 付近まで高い剛性を維持す ることが可能であり，耐熱性と透明性とを有した FRTP として使用できる可能性がある.

\section{5. 結}

\section{言}

本研究では，イオン液体を溶媒とした溶媒法による FRTP のプリプレグの基本的な作製方法の提案を行い, 実際にイオン液体を溶媒としたプリプレグを作製し，そ のプリプレグをプレス成形して得られた FRTPの機械 的特性を測定した。そして，その特長を従来から用いら れているフィルムスタッキング法で得られた FRTP と 比較，評価した。その結果，以下の結論が得られた。

1）今回，選定したポリアミド樹脂（MXD6）とポリエ ーテルサルフォン樹脂（PES）の 2 種類の熱可塑性 樹脂に関しては，イオン液体への溶解条件を適切に 選定することで，重量平均分子量，数平均分子量お よび分子量分布を変化させることなく，イオン液体 で溶解することが可能である。

2）本研究で提案したイオン液体を溶剤とした溶媒法に よるプリプレグを用いた FRTP は，従来から用い られているフィルムスタッキング法で得られた FRTPよりも良好な含浸状態が得られる。
3）本研究で提案したイオン液体を溶剤とした溶媒法に よるプリプレグを用いた FRTP は,フィルムスタッ キング法と比較して，高い機械的特性が得られる。

\section{参 考 文 献}

1）松本隆之：日本複合材料学会誌，36,4（2010）, 119122 .

2) N. Odagiri, H. Kishi \& M. Yamashita: $A d v$. Compos. Mater., 5, 3 (1996), 249-254.

3) R.G. Lenferink, D.W. Hendrikus \& M.V. Dreumel : Method for manufacturing a dimensionally stable fabric cloth and fabric cloth obtained therewith, EP 1005979 A2, Ten Cate Advanced Composites B.V. (2000).

4) M. Ostgathe, C. Mayer \& M. Neitzel : Polym. Polym. Compos., 4, 7 (1996), 505-512.

5）日本機械工業連合会，次世代金属 - 複合材料研究開 発協会: 平成 19 年度熱可塑性樹脂複合材料の機械 工業分野への適用に関する調査報告書 (2008).

6) ビーエーエスエフソシエタス・ヨーロピア：合成ポ リマーから多孔質構造物を製造する方法, 特表 2011 514401 (2006).

7）ザ ユニヴァーシティー オブ アラバマ：イオン 性液体中におけるポリマー溶解及びブレンド生成, 特許 5203698 (2005).

8）大野弘幸監修：イオン液体 II 一驚異的な進歩と多彩 な近末来，シーエムシー出版 (2006), pp. 4-15.

9）大野弘幸監修：イオン液体 II一驚異的な進歩と多彩 な近未来，シーエムシー出版 (2006)，pp. 127-133, $138-143$

10）住ベリサーチ株式会社：イオン性液体・常温溶融塩 の最新応用 II，住ベリサーチ株式会社 (2011), pp. 17-278.

11) D. Ingildeev, F. Effenberger, K. Bredereck, F. hermanutz \& M.R. Buchmeiser : Comparison of processing techniques for man-made cellulosics, 50th Dornbirn Man-Made Fibers Congress, Dornbirn, Austria (2011). 